\section{Australian Journal of \\ Crop Science}

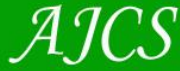

ISSN:1835-2707

\title{
Agronomic performance and protein content of Pereskia aculeata Mill. using organic chicken manure fertilizer
}

\author{
José Rodrigo de Araújo Guimarães*, Jordany Aparecida de Oliveira Gomes, Daniela Aparecida Teixeira, \\ Filipe Pereira Giardini Bonfim, Regina Marta Evangelista
}

\author{
Departament of Horticulture, São Paulo State University “Júlio de Mesquita Filho", School of Agriculture (FCA), José \\ Barbosa de Barros, no 1.780, ZIP: 18610-307, Botucatu, SP, Brasil
}

*Corresponding author: rodrigoagronomoal@yahoo.com.br

\begin{abstract}
Pereskia aculeata Mill is a rustic and perennial plant, developing well in various types of soil, both in the shade and in the sun. It is a plant with high nutritional potential indicated as an alternative food. The current study aimed to evaluate yield and protein content of Pereskia aculeata Mill. under different levels of organic chicken manure fertilizer. A completely randomized design was conducted with five treatments and four replicates. Replications consisted of two experimental plots that contained 'ora-pro-nobis' plant. The treatments referred to different levels of organic chicken manure fertilizer, such as T1_control (soil $+0 \mathrm{~kg} \mathrm{~m}^{-2}$ of chicken manure); T2_(soil $+2 \mathrm{~kg} \mathrm{~m}^{-2}$ of chicken manure); T3_(soil $+4 \mathrm{~kg} \mathrm{~m}^{-2}$ of chicken manure); T4_(soil $+6 \mathrm{~kg} \mathrm{~m}^{-2}$ of chicken manure); T5_(soil $+8 \mathrm{~kg} \mathrm{~m}^{-2}$ of chicken manure). The following traits were evaluated: shoot length $(\mathrm{cm})$; total leaf area; leaf number; root length $(\mathrm{cm})$; root volume $(\mathrm{mL})$; root dry mass $(\mathrm{g})$; shoot fresh mass $(\mathrm{g})$; shoot dry mass $(\mathrm{g})$ and crude protein content $\left(\mathrm{g} 100 \mathrm{~g}^{-1}\right)$. Results indicated significant increase in yield and protein content of Pereskia aculeata $\left(12.21 \mathrm{~g} 100 \mathrm{~g}^{-1}\right)$ by enhancing the levels of chicken manure. Therefore, a recommendation of $3.5 \mathrm{~kg} \mathrm{~m}^{-2}$ of chicken manure can be made on soils of average fertility using in organic farming systems under similar conditions to this experiment.
\end{abstract}

Keywords: Pereskia aculeata Mill.; cactaceae; non-conventional plant; alternative food; edible plants.

Abbreviations: SL_shoot length; TLA_total leaf area; LN_leaf number; RL_root length; RV_root volume; RDM_root dry mass; SFM_ shoot fresh mass; SDM_shoot dry mass; CPC_crude protein content.

\section{Introduction}

In traditional medicine, Pereskia aculeata is used in the treatment of anti-inflammatory and cutaneous lesions caused by burns. The leaves are popularly used as emollient; and fruits used as expectorants and to treat syphilis (Duarte and Hayashi, 2005; Rosa and Souza, 2003; Sator et al., 2010). Organic food production has increased over recent years, mainly due to population demand for more sustainable alternatives and higher quality products; making it necessary to search new techniques to improve farming systems, focusing on the quality and efficiency of nutritional management. Nitrogen is crucial for plant growth and is available to them in the soil and organic animal fertilizers (Lisboa et al., 2007). In addition to providing nutrients that are released via mineralization process, organic fertilizers are the source of energy for microorganisms that improves soil structure and moisture-holding capacity.

Chicken manure is an example of organic fertilizer that contains high nitrogen content. Also, such fertilizer could in time complete or partially replace chemical fertilizer, since ensuring proper management (Blum et al., 2003). Besides, they have a regulatory effect on soil temperature; retarding phosphorus fixation; increasing cation exchange capacity of soil; and reducing nutrients leaching such as potassium, calcium and magnesium (Malavolta et al., 2002). Plant nutrition is among the factors that interfere with the chemical composition of the plant, since deficiency or excess nutrients can interfere in the production of biomass and in the quantity of active principle (Mapeli, 2005). Synthetic fertilizers when available in the soil can be lost much by leaching, volatilization or fixation. Organic fertilizers are gradually released nutrients for longer in the soil to meet the needs of vegetables. It is necessary that the vegetal material is well decomposed, for a greater effect of aggregation in the soil. For example, humus is an intermediate product of decomposition differentiating itself from vegetable remains that still need to pass through this process, that is, so that the plant remains reach the humus state must pass through the composting (Primavesi, 1987). Fertilization is responsible for improvement of production and quality of most plant species. As in other crops, medicinal and aromatic plants also need good nutrition for good agricultural productivity. It is in this sense that organic fertilization has importance in providing nutrients to plants and improvement of the physical, chemical and biological qualities of the soil 
(Corrêia, 2010). The interest in organic products stimulated the search for studies in the development of new techniques for this production system, in the search for better efficiency mainly in nutrient management. It is also important to highlight the the availability of nitrogen from sources of plant or animal organic fertilizers or even what is available in soil organic matter (Lisboa et al., 2007). One of the most widely available and accessible organic materials among producers in several regions of Brazil is manure, which can be cattle, horses, pigs and chicken. Besides being an excellent source of organic matter, the daily production per animal has an expressive value. For example, a cow with a mean weight of $453 \mathrm{~kg}$ produces about $23.5 \mathrm{~kg}$ of manure per day, whereas a chicken with approximately $1.6 \mathrm{~kg}$ produces about $100 \mathrm{~g}$ of manure plus urine. In relation to the use of organic compost and bovine manure, the bed of chicken is the richest in nutrients, standing out in it has high content of nitrogen total, $\mathrm{N}$-ammonium and phosphorus, as well as Ca, S and B (Silva, 2010). In addition, they act to reduce soil phytopathogens and improve the production of some crops (Blum et al., 2003). Thus, the use of chicken manure stands out among other organic fertilizers from animal origin, as it allows better production compared to commercial organic composts.

By considering the protein potential of Pereskia aculeata and the need for alternatives to organic farming systems, the current study aimed to evaluate yield and protein content of Pereskia aculeata Mill. under different levels of organic chicken manure fertilizer.

\section{Results and discussion}

\section{Agronomic performance of plants of Pereskia aculeatta}

Results indicated that there was a significant increase in the yield of Pereskia aculeata up to a certain level of chicken manure. The Table 3 shows a significant influence of different levels of organic chicken manure fertilizer through analysis of variance $(p \leq 0.01)$, which can be attributed to the greater availability of organic matter in soil, meeting plants' nutritional needs.

Through a literature search on the use of organic fertilizers, similar results were found in other species. By using cattle manure, Oliveira et al. (2009) obtained higher yield of maxixe (Cucumis anguria) fruit. Therefore, organic matter is beneficial to supply nutrients to plants at proper level. The use of organic fertilizer also enhanced yield of onions according to Vidigal et al. (2010).

By applying $3.5 \mathrm{~kg} \mathrm{~m}^{-2}$ of chicken manure, maximum yield was obtained in leaf number (LN), shoot fresh mass (SFM) and leaf area (LA): 12.19; $130.77 \mathrm{~g}$ and $2504.05 \mathrm{~cm}^{2}$, respectively (Fig. 1). Such results indicated that levels of chicken manure greater than $3.5 \mathrm{~kg} \mathrm{~m}^{-2}$ are not recommended. Carvalho (2013) verified that shoot fresh mass of Pereskia aculeata differed statistically in the absence and presence of substrate and manure, i.e. $16.06 \mathrm{~g}$ (soil + manure) and 15.78g (sand + manure). Also, highest mean was obtained in stem fresh mass, i.e. 23.08g (sand + manure) and $19.48 \mathrm{~g}$ (soil + manure); while mean weight among treatments did not differ statistically in the absence of cattle manure. In the same study, Carvalho (2013) obtained $21.66 \mathrm{~g}$ (sand + cattle manure) in root fresh mass, followed by $14.40 \mathrm{~g}$ (soil + manure), such results differed statistically from treatments without cattle manure, as they presented the lowest mean weight, that is, between $2.80 \mathrm{~g}$ and $5.80 \mathrm{~g}$.

For shoot length $(\mathrm{SL})$, root volume (RV), shoot dry mass (SDM) and root dry mass (RDM), the application of $3.0 \mathrm{~kg} \mathrm{~m}^{-2}$ provided the maximum yields, i.e. $72.2 \mathrm{~cm} ; 48.7 \mathrm{~mL} ; 20.9 \mathrm{~g}$ and $10.84 \mathrm{~g}$ (Fig. 2); showing the ideal level of organic fertilizer; consequently, meeting plant's nutritional needs and better yield per square meter harvested.

Regarding to the yield, similar results were found in plants from the same family (Cactaceae). Santos (2000) observed an increase of $81 \%$ in the shoot dry mass production of Opuntia fícus-indica L. Miil. by using $10 \mathrm{t} \mathrm{ha}^{-1}$ of tanned manure corral; however, the level of $20 \mathrm{t} \mathrm{ha}^{-1}$ of chicken manure was $59 \%$ higher in shoot dry mass than control treatment in the current study. The larger the leaf area or the size of the cladodes, the more important they are to Cactaceae, since they will capture more light; consequently, obtaining great water reserves per unit leaf area; producing more carbohydrates, vital for plant growth; greater photosynthetic capacity per unit leaf area; and higher yields per square meter area (Ramos, 2012).

In studies carried out with arracacha (Arracacia xanthorrhiza Bancroft), also an unconventional vegetable, it was recommended to use $10 \mathrm{t} \mathrm{ha}^{-1}$ of semi-composted chicken manure to obtain higher yield and high-bromatological components, such as proteins, lipids, carbohydrates, fibres and total caloric value (Graciano et al., 2006).

Regarding to root length (RL), control treatment presented $42.42 \mathrm{~cm}$ (Fig. 3). However, root length was smaller $(16.00 \mathrm{~cm})$ than other treatments at $8 \mathrm{~kg} \mathrm{~m}^{-2}$ of chicken manure, this fact is due to the great availability of nutrients in the environment; consequently, roots do not grow in search of nutrients; besides that, over-fertilization results in root toxicity. Such results corroborates the one found by Gassi et al.(2009), who evaluated burdock (Arctium lappa L., Asteraceae) under different levels of phosphorus $(4.3,25.8$, 43.0, 60.2 and $81.7 \mathrm{~kg} \mathrm{ha}^{-1}$ ) and organic chicken manure fertilizer $\left(1 ; 6 ; 10 ; 14\right.$ and $\left.19 \mathrm{t} \mathrm{ha}^{-1}\right)$; found that higher levels of chicken manure, regardless of phosphorus doses, increased in dry mass production of burdock leaves. However, the highest yields of root dry mass were obtained only with the highest levels of phosphorus and intermediate levels of chicken manure.

\section{Analysis of protein content}

Through analysis, it was observed that protein content increased at higher levels of chicken manure, obtaining a linear behaviour. The application of $8 \mathrm{~kg} \mathrm{~m}^{-2}$ of organic compost in Pereskia aculeata contributed to produce $12.21 \mathrm{~g}$ of protein per $100 \mathrm{~g}^{-1}$ of dry mass. In control treatment (i.e. 0 $\mathrm{kg} \mathrm{m}^{-2}$ ), it was verified $6.34 \mathrm{~g}$ of protein per $100 \mathrm{~g}^{-1}$ of dry mass (Fig. 3).

Results indicated that the higher the dose of chicken manure, the higher the protein content in the leaves of 'orapro-nobis'. Moreover, there was enough available nitrogen in the soil; consequently, high protein content in leaves by increasing the levels of organic chicken manure fertilizer, which is an essential source of nitrogen. 
Table 1. Chemical soil analysis used in the experiment.

\begin{tabular}{|c|c|c|c|c|c|c|c|c|c|c|c|c|}
\hline SAMPLE & $\mathrm{pH}$ & O.M. & $P_{\text {resin }}$ & $\mathrm{Al}^{3+}$ & $\mathrm{H}+\mathrm{Al}$ & $\mathrm{K}$ & $\mathrm{Ca}$ & $\mathrm{Mg}$ & SB & CEC & V\% & \\
\hline Int. & $\mathrm{CaCl}_{2}$ & $\mathrm{~g} / \mathrm{dm}^{3}$ & $\mathrm{mg} / \mathrm{dm}^{3}$ & & & $\mathrm{mmo}$ & $\mathrm{dm}^{3}$ & & & & & $\mathrm{mg} / \mathrm{dm}^{3}$ \\
\hline 1 & 4.2 & 12 & 9 & 6 & 40 & 1.2 & 7 & 2 & 10 & 50 & 20 & 12 \\
\hline
\end{tabular}
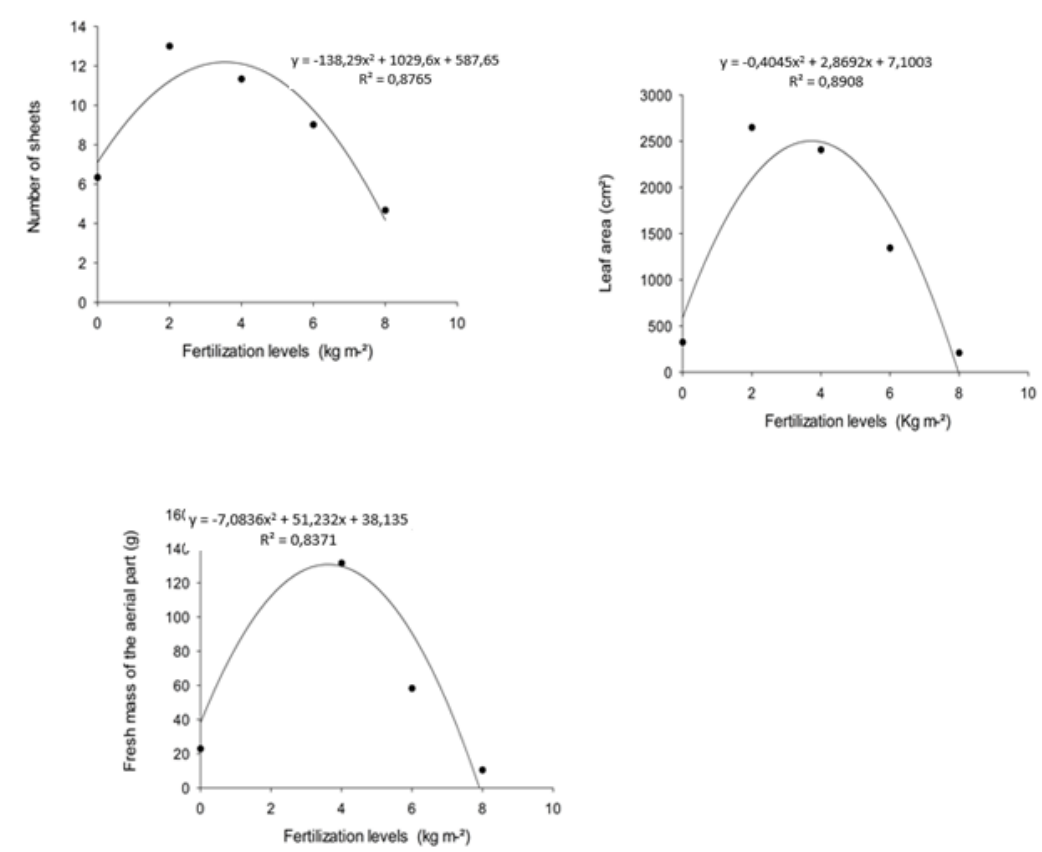

Fig 1. Leaf number, shoot fresh mass $(\mathrm{g})$ and leaf area $\left(\mathrm{cm}^{2}\right)$ of ora-pro-nobis (Pereskia aculeata Mill.) under different levels of chicken manure fertilizer

Table 2. Chemical analysis of organic chicken manure fertilizer used in the experiment.

\begin{tabular}{|c|c|c|c|c|c|c|c|c|c|c|c|}
\hline SAMPLE & $\mathrm{N}$ & $\mathrm{P}_{2} \mathrm{O}_{5}$ & $\mathrm{~K}_{2} \mathrm{O}$ & $\mathrm{Ca}$ & $\mathrm{Mg}$ & $S$ & $M$ & OM & C & $\mathrm{pH}$ & $\mathrm{C} / \mathrm{N}$ \\
\hline & 4.1 & 5 & 4 & 3 & 1 & 0.7 & 10 & 61 & 34 & 7 & 8 \\
\hline
\end{tabular}

$\mathrm{N}$ - nitrogen; PsO5 - phosphorus; K2O - potassium; Ca - calcium; Mg - magnesium; S-sulphur; M - moisture; OM - organic matter; C - carbon; C/N - carbon nitrogen ratio.
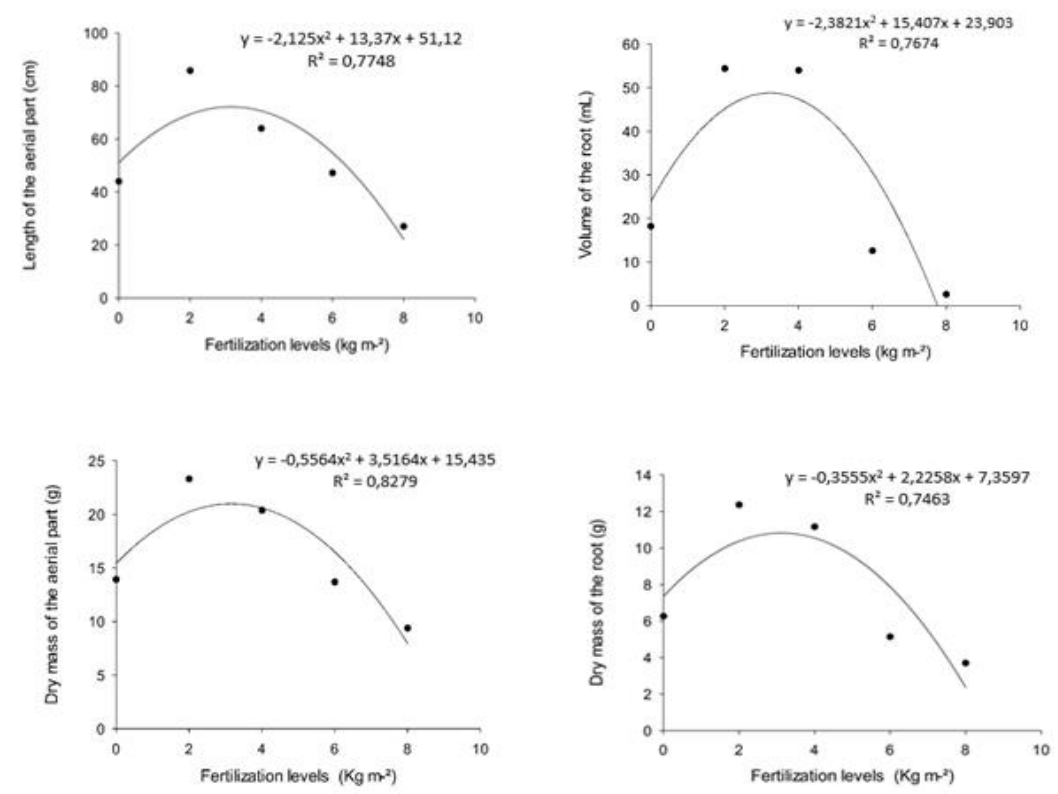

Fig 2. Shoot length $(\mathrm{cm})$, root volume $(\mathrm{mL})$, shoot dry mass $(\mathrm{g})$ and root dry mass $(\mathrm{g})$ of 'ora-pro-nobis' (Pereskia aculeata Mill.) under different levels of chicken manure fertilizer. 
Table 3. Adjusted equations and coefficients of determinations for leaf number (LN), shoot length (SL), shoot fresh mass (SFM), leaf area (LA), root volume (RV), leaf length (LL), shoot dry mass (SDM), root dry mass (RDM) and crude protein (CP) under different levels of chicken manure.

\begin{tabular}{lc}
\hline Adjusted equations & Coefficients of determinations \\
\hline $\mathrm{LF}=-0.4045 \mathrm{x}^{2}+2.8692 x+7.1003^{* *}$ & 0.89 \\
$\mathrm{SL}=-2.125 \mathrm{x}^{2}+13.37 \mathrm{x}+51.12^{* *}$ & 0.77 \\
$\mathrm{SFM}=-7.0836 \mathrm{x}^{2}+51,232 \mathrm{x}+38,135^{* *}$ & 0.84 \\
$\mathrm{LA}=-138.29 \mathrm{x}^{2}+1029.6 x+587.65^{* *}$ & 0.88 \\
$\mathrm{RV}=-2.3821 \mathrm{x}^{2}+15.407 x+23.903^{* *}$ & 0.77 \\
$\mathrm{LL}=-0.2071 \mathrm{x}^{2}-1.0429 x+41.103^{* *}$ & 0.77 \\
$\mathrm{SDM}=-0.5564 \mathrm{x}^{2}+3.5164 x+15.435^{* *}$ & 0.83 \\
$\mathrm{RDM}=-0.3555 \mathrm{x}^{2}+2.2258 \mathrm{x}+7.3597^{* *}$ & 0.75 \\
$\mathrm{CP}=0.1644 \mathrm{x}+1.0612^{* *}$ & 0.93 \\
\hline${ }^{* *}$ Significant by F test at $1 \%$ probability. &
\end{tabular}
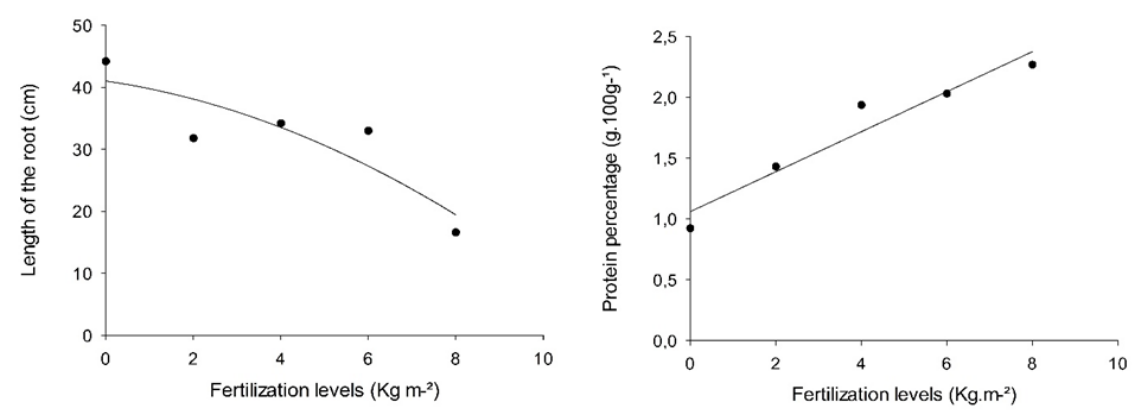

Fig 3. Root length and protein content in 'ora-pro-nobis' (Pereskia aculeata Mill.) under different levels of chicken manure fertilizer.

However, the protein content (Fig. 3) per dry mass of Pereskia aculeata was lower than those identified by Almeida et al (2014), who obtained 28.99g of protein per $100 \mathrm{~g}^{-1}$ of dry mass; and by Takeiti et al. (2009), who verified $28.4 \mathrm{~g}$ of protein per $100 \mathrm{~g}^{-1}$ of dry mass. Although, the result of the current study was like that one observed by Queiroz (2012), i.e. $11.9 \mathrm{~g}$ of protein per $100 \mathrm{~g}^{-1}$ of dry mass.

The current study corroborates with a study performed by Guimarães et al. (2013) on protein content of Pereskia aculeata under different levels of nitrogen by the Bradford and Kjeldahl methods. The total protein increased up to the level of $100 \mathrm{~kg} \mathrm{~N} \mathrm{ha}^{-1}$ by Kjeldahl method. Soluble protein increased in the doses of $\mathrm{N}$ between 50 and $200 \mathrm{~kg} \mathrm{ha}^{-1}$ by Bradford method. Furthermore, it was verified that total protein increased significantly from 0 to $50 \mathrm{~kg} \mathrm{~N} \mathrm{ha}^{-1}$ by Kjeldahl method; while variation was lower above $100 \mathrm{~kg} \mathrm{~N}$ $\mathrm{ha}^{-1}$. These results show that there is an optimum fertilizer dose to obtain excellent levels of both yield and nutrients in plants.

The increase in protein content occurs in proportion to the amount of nitrogen absorbed, since it is reduced to the ammoniacal form and used in the synthesis of glutamic acid (Andrade et al., 2003).

Pereskia aculeata is considered an unconventional vegetable, which is source of protein, and may vary according to climatic factors, fertilization methods and growing period. In general, analysis indicated that organic chicken manure fertilizer provided higher biomass yields and protein yield.

\section{Materials and methods}

\section{Study area}

The current experiment was conducted in the experimental area of the Horticulture Department, School of Agriculture,
Botucatu, UNESP $\left(22^{\circ} 50^{\prime} \mathrm{S}, 48^{\circ} 26^{\prime} \mathrm{W} ; 817 \mathrm{~m}\right.$ altitude). The climate of the region is hot and humid (Cwa), i.e. dry winter, hot and rainy summer, according to Köppen classification) and annual average temperature of 19,3 ㅇ․ The mean annual rainfall is $1501.4 \mathrm{~mm}$ and $71 \%$ relative humidity (Cunha et al., 1999).

The soil of the experiment was classified as dystrophic Red Latosol (Embrapa, 2006) and collected in the ravine area of the orchard at the Department of Horticulture-UNESP in Botucatu.

\section{Experimental design}

The experiment was conducted from July to November 2014. Before its installation, soil samples were collected for the determination of chemical composition (Table 1) and the chemical analysis of the organic chicken manure fertilizer is shown in Table 2. The amount of organic fertilizer applied was calculated in fresh weight and contained $10 \%$ moisture. The seedlings of Pereskia aculeata were obtained through vegetative propagation, taking live cuttings from a matrix in the medicinal plants orchard of Centroflora Company. Thus, apical cuttings were prepared with $15 \mathrm{~cm}$ in length. The Pereskia aculeata cuttings have grown a period of 60 days, in polyethylene bibs covered by monofilament shade cloth $50 \%$ at the plant nursery. Afterwards, they were transplanted into $5 \mathrm{~L}$ pots, in which contained the soil and treatments.

Harvest was performed at 120 days. Afterwards, plants were divided into root, stem and leaf. For shoot and root dry mass production, they were separated and packed in paper bags and dried in a forced-air-circulation oven at $65^{\circ} \mathrm{C}$ until constant mass.

The experiment was performed in a complete randomized block design, with five treatments and four replicates. The treatments were composed of plants Pereskia aculaeta. Replicates consisted of two plots and each plot had Pereskia 
aculeata, being one for yield analysis and the other for protein analysis; therefore, a total of 20 plants per analysis. The treatments were obtained under different levels of organic chicken manure fertilizer, as follows: T1_control (soil $+0 \mathrm{~kg} \mathrm{~m}^{-2}$ of chicken manure); $\mathrm{T} 2$ (soil $+2 \mathrm{~kg} \mathrm{~m}^{-2}$ of chicken manure); T3_(soil $+4 \mathrm{~kg} \mathrm{~m}^{-2}$ of chicken manure); T4_(soil + 6 $\mathrm{kg} \mathrm{m}^{-2}$ of chicken manure); T5_(soil $+8 \mathrm{~kg} \mathrm{~m}^{-2}$ of chicken manure). Sprinkler irrigation was used.

\section{Characteristics evaluated}

The following characteristics were evaluated: plant length $(\mathrm{cm})$ were determined using a tape measure from basal end to the apex of the plant; total leaf area $\left(\mathrm{cm}^{2}\right)$ were determined using an area meter LI-3.100, LICOR; leaf number; root length $(\mathrm{cm})$ were determined using tape measure; root volume $(\mathrm{mL})$ were determined by volume change using $100 \mathrm{~mL}$ beaker; root dry mass (g), shoot dry mass $(\mathrm{g})$ and shoot fresh mass $(\mathrm{g})$ were weighed in digital scale; and leaf weight ratio were calculated according to Benincasa (2003).

Crude protein (\%) was performed in dry mass of Pereskia aculeata. Sulfuric digestion and determination of the total $\mathrm{N}$ were carried out by steam stripping. The factor 6.25 was used to convert the nitrogen content into crude protein (CP), i.e. total nitrogen $\times 6.25$, according to AOAC (2005).

\section{Statistical analysis}

Data were submitted to analysis of variance through $\mathrm{F}$ test and polynomial regression. Means were compared by Tukey test $5 \%$ of probability, using the Assistat 7.7 Beta program.

\section{Conclusion}

Results indicated that Pereskia aculeata presented excellent yield and high protein value by applying organic chicken manure fertilizer, being an alternative to organic food production. Yield and protein content were influenced by increasing the level of organic fertilizer. The level of $3.5 \mathrm{~kg}$ $\mathrm{m}^{-2}$ of organic chicken manure fertilizer is sufficient for high quality and yield of Pereskia aculeata. Therefore, a recommendation may be done in organic farming systems under similar conditions.

\section{Acknowledgments}

The authors would like to thank to Centroflora company; and the scholarship granted by CAPES.

\section{References}

Aguiar RS, Vasquez HM, Silva JFC (2000) Produção e composição química-bromatológica do capim-furacão (Panicum repens L.) sob adubação e diferentes idades de corte. R bras Zootec. 29(2):325-333.

Almeida MEF, Junqueira AMB, Simão AA, Corrêa AD (2014) Caracterização química das hortaliças não-convencionais conhecidas como ora-pro-nobis. Biosci J. 30(3): 431-439.

Andrade AC, Fonseca DM, Queiroz DS (2003) Adubação nitrogenada e potássica emcapim-elefante (Pennisetum purpureum Schum. cv. Napier). Ciênc agrotec. 1643-1651.
AOAC International (2005) AOAC Official Method 94802: starch in plants: titrimetric method. 18nd edn. Gaithersburg. 3: 25.

Benincasa MMP (2003) Análise de crescimento de plantas. (noções básicas). 2nd edn. Jaboticabal: Funep.

Blum LEB, Amarante CVT, Guttler G, Macedo AF, Kothe DM, Simmler AO, Prado G, Guimarães LS (2003) Produção de moranga e pepino em solo com incorporação de cama aviária e casca de pinus. Hortic bras. 21(4): 627-631.

Carvalho EG (2013) Efeito dos diferentes substratos no desenvolvimento de Pereskia aculeata Mill. (Cactaceae) e ação do extrato bruto etanólico na sicatrização in vitro. Dissertação de Mestrado, Instituto de Pesquisa e Desenvolvimento, Universidade do Vale do Paraíba, São José dos Campos.

Cunha AR, Klosowski ES, Galvani E (1999) Clas sificação Climática para o município de Botucatu, SP, segundo Köppen. In: I Simpósio em energia na agricultura. Botucatu. 490-491.

Duarte MR, Hayashi SS (2005) Estudo anatômico de folha e caule de Pereskia aculeata Mill.(Cactaceae). Rev bras farmacogn. 15(2): 103-109.

EMBRAPA-Empresa Brasileira de Pesquisa Agropecuária (2006). Centro Nacional de Pesquisa de Solos. Sistema Brasileiro de Classificação de Solos. 2nd edn. Rio de Janeiro. 306p.

Gassi RP, Zárate RP, Vieira NAH, Scalon MC, Mattos SPQ, Abreu JK (2009) Doses de fósforo e de cama-de-frango na produção de bardana. Ciênc agrotec. 33 (3): 692-697.

Guimarães DSPSF, Souza MRM, Hirano RT, Pereira PRG, Pereira MCB (2013) Concentração de proteína solúvel por Bradford revela diferenças no metabolismo de plantas de ora-pro-nobis em diferentes doses de nitrogênio. Rev bras agropec sust. 3(1): 40-44.

Graciano JD, Zárate NAH, Vieira MC, Rosa YBCJ, Sediyama MAN, Rodrigues ET (2006) Efeito da cobertura do solo com cama-de-frango semidecomposta sobre dois clones de mandioquinha-salsa. Acta Sci. 28(3): 365-371.

Kazama CC, Uchida DT, Canzi KN, Souza P, Crestani S, Gasparotto A, Laverde A (2012) Involvement of argininevasopressin in the diuretic and hypotensive effects of Pereskia grandifolia Haw. J Ethnopharmacol. 144(1): 8693.

Kinupp VF (2066) Plantas alimentícias alternativas no Brasil: uma fonte complementar de alimento e renda. ABA J. 1: 333-336.

Lisboa CC, Costa SEVGA, Castro DM, Marques JJ (2007) Efeito da Homeopatia Ammonium carbonicum na minimização da lixiviação de nitrato. Ciênc agrotec. 31(2): 317-325.

Malavolta E, Pimentel-Gomes F, Alcarde JC. Adubos e adubações. São Paulo: Nobel, 2002. 200 p.

Mercê ALR, Landaluze JS, Mangrich AS, Szpoganicz B, Sierakowski MR (2000) Complexes of arabinogalactan of Pereskia aculeata and $\mathrm{Co}^{2+}, \mathrm{Cu}^{2+}, \mathrm{Mn}^{2+}$, and $\mathrm{Ni}^{2+}$. Bioresour Technol. 76(1): 29-37.

Oliveira ANP, Oliveira AP, Leonardo FAP, Cruz IS, Silva DF (2009) Yield of gherkin in response to doses of bovine manure. Hortic bras. 27(1): 100-102.

Queiroz CRAA (2012) Cultivo e composição química de Orapro-nóbis (Pereskia aculeata Mill.) sob déficit hídrico intermitente no solo. 2012. 144 f. Tese (Doutorado em Agronomia). Faculdade de Ciências Agrárias e Veterinárias, Universidade Estadual Paulista, Jaboticabal, SP. 
Raij BV, Andrade JC, Cantarella H, Quaaggio JA. Análise Química para Avaliação da Fertilidade de Solos Tropicais. IAC. 2001. 285p

Ramos JPF (2012) Crescimento vegetativo e rendimento forrageiro em função do manejo de colheita e da adubação orgânica de palma forrageira. 2012. $57 \mathrm{f}$. Dissertação (Mestrado em Zootecnia). Universidade Federal da Paraíba. Areia, PB.

Rocha DRC, Pereira Júnior GA, Vieira G, Pantoja L, Santos AS, Pinto NAVD (2008) Macarrão adicionado de ora-pro-nóbis (Pereskia aculeata Miller) desidratado. Alim Nutr. 19(4): 459-465.

Rosa SM, Souza LA (2003) Morfo-anatomia do fruto (hipanto, pericarpo e semente) em desenvolvimento de Pereskia aculeata Miller (Cactaceae). Acta sci Biol sci. 2(2): 415-428.

Santos DC, Lira MA, Dias FM, Farias I, Santos MVF, Santos VF (2000) Produtividade de cultivares de palma forrageira
(Opuntia e Nopalea). In: Congresso Nordestino de Produção Animal. Anais... Teresina. 2: 121-123.

Sartor CFP, Amaral V, Guimarães HET, Barros KN, Felipe DF, Cortez LER, Veltrini VC (2010) Estudo da ação cicatrizante das folhas de Pereskia aculeata. Rev Saúde e Pesquisa. 3(2): 149-154.

Souza VC, Lorenzi H (2005) Botânica Sistemática: guia ilustrado para identificação das famílias de angiospermas da flora brasileira, baseado em APG II. Nova Odessa, São Paulo, SP. Instituto Plantarum. 230-231.

Takeiti CY, Antonio GC, Motta EM, Collares-Queiroz FP, Park KJ (2009) Nutritive evaluation of non-conventional leafy vegetable (Pereskia aculeata Miller). Int J Food Sci Nutr. 60(1): 148-60.

Vidigal SM, Sediyamai MAN, Pedrosai MW, Santos MR (2010) Produtividade de cebola em cultivo orgânico utilizando composto à base de dejetos de suínos. Hortic bras. 28 (2): 168-173. 